\title{
Application of the Snowmelt Runoff Model in the Salang River Basin, Afghanistan Using MODIS Satellite Data
}

\author{
Hedayatullah Arian ${ }^{1,2}$, Rijan B. Kayastha1, Bikas C. Bhattarai ${ }^{1}$, \\ Ahuti Shrestha ${ }^{1}$, Hafizullah Rasouli ${ }^{1,3}$ Richard Armstrong ${ }^{4}$ \\ ${ }^{1}$ Himalayan Cryosphere, Climate and Disaster Research Centre, Department of Environmental \\ Science and Engineering, School of Science, Kathmandu University, Dhulikhel, Nepal \\ ${ }^{2}$ Department of Hydro-Meteorology, Faculty of Geosciences, Kabul University, Kabul, Afghanistan \\ ${ }^{3}$ Department of Geology, Faculty of Geosciences, Kabul University, Kabul, Afghanistan \\ ${ }^{4}$ National Snow and Ice Data Centre, The University of Colorado, Boulder, USA
}

\begin{abstract}
This study is carried out on the Salang River basin, which is located at the northern part of the Kabul River basin, and in the south facing slope of the Hindu Kush Mountains. The basin drains through the Salang River, which is one of the tributaries of the Panjshir River. The basin covers an area of $485.9 \mathrm{~km} 2$ with a minimum elevation of $1653 \mathrm{~m}$ a. s. $l$. and a maximum elevation of $4770 \mathrm{~m}$ a. s. $l$. The Salang River sustains a substantial flow of water in summer months due to the melting of snow. In this study, we estimate daily discharge of Salang River from 2009 to 2011 using the Snowmelt Runoff Model (SRM, Version 1.12, 2009), originally developed by J. Martinec in 1975. The model uses daily observed precipitation, air temperature and snow cover data as input variables from which discharge is computed. The model is calibrated for the year 2009 and validated for 2010 and 2011. The observed and calculated annual average discharges for the calibration year 2009 are $11.57 \mathrm{~m}^{3} \mathrm{~s}^{-1}$ and $10.73 \mathrm{~m}^{3} \mathrm{~s}^{-1}$, respectively. Similarly, the observed and calculated annual average discharges for the validation year 2010 are $11.55 \mathrm{~m}^{3} \mathrm{~s}^{-1}$ and $10.07 \mathrm{~m}^{3} \mathrm{~s}^{-1}$, respectively and for 2011, the discharges are $9.05 \mathrm{~m}^{3} \mathrm{~s}-1$ and $9.6 \mathrm{~m}^{3} \mathrm{~s}^{-1}$, respectively. The model is also tested by changing temperature and precipitation for the year 2009. With an increase of $1{ }^{\circ} \mathrm{C}$ in temperature and $10 \%$ in precipitation, the increases in discharge for winter, summer and annually are $21.8 \%, 13.5 \%$ and $14.8 \%$, respectively. With an increase of $2{ }^{\circ} \mathrm{C}$ in temperature and $20 \%$ in precipitation, the increases are $48.5 \%, 43.3 \%$ and $44.1 \%$, respectively. The results obtained suggest that the SRM can be used as a promising tool to estimate the river discharge of the snow fed mountainous river basins of Afghanistan and to study the impact of climate change on river flow pattern of such basins.
\end{abstract}

Keywords: Snowmelt Runoff Model (SRM), Salang River basin, snowmelt, river discharge

\section{INTRODUCTION}

Afghanistan is a country dominated by a dry climate with most of the area represented by arid land. The population of this country mostly uses mountain fed river water for irrigation, hydropower, and drinking water purposes. The 
effect of global climate change on hydrologic systems, especially on mountain snow and glacier melt, can modify the timing and amount of runoff in mountainous watersheds. Therefore, accurate stream flow simulation and forecast is of great importance to water resources management and planning (Abudu et al., 2010).

The high mountain snow and glaciers of Afghanistan are at high risk due to the climate change phenomenon. In the summer season, there is high snow melt and retreat of snow cover. The great amount of this melt water reliably occurs at this particular time of the year. To minimize the risk and loss from floods caused by rapid snow and glacier melt, accurate forecasting is essential (Li and Williams, 2008). However, water resource management and the evaluation of impacts of climatic change require quantification of stream flow variability and hydrologic models provide a framework to investigate these relationships (Leavesley, 1994). In addition potential impacts of climate change on stream-flow regimes can be evaluated if valid snow-glacier models are available (Hong and Guodong, 2003).

There are three methods to estimate snow melt runoff: (a) degree day method, (b) energy budget method, and (c) combination method. Of these three methods, the degree day method has the most application, because of the simplicity and accuracy (Raghunath, 2006). The Snowmelt Runoff Model (SRM) also referred as the "Martinec Model" or "Martinec-Rango Model" originally developed by Martinec (1975) in small European basins. This model is based on the degree day model and is designed to simulate and forecast the daily stream flow in mountain basins where snowmelt is a major runoff factor. SRM also successfully underwent tests by the World Meteorological Organization (WMO) with regard to runoff simulation (WMO, 1986) and to simulated conditions of real time runoff forecasts (WMO, 1992). The SRM with the progressive use of remote sensing data for snow cover is widely applied in practice by various agencies, institutes and universities in different parts of the world (Martinec et al., 1983). SRM or variations of it have been applied in over 100 basins in 25 countries around the world with basin sizes varying from $<1$ to $120,000 \mathrm{~km} 2$ (Seidel and Martinec, 2004). With input of climatic variables and parameter selection methods, SRM has a potential in forecasting stream flow and evaluating the effects of climate change on runoff in mountainous watersheds, especially data-scarce watersheds in high-elevation regions. Therefore, we use this SRM model in Salang River basin having limited data.

\section{STUDY AREA}

The Salang River basin is located at the northern part of the Kabul River basin and in the south facing slope of the Hindu Kush Mountains. It lies between the Panjshir and Ghorband Valleys, which drain water from the central Hindu Kush Mountains (Favre and Kamal, 2004). It

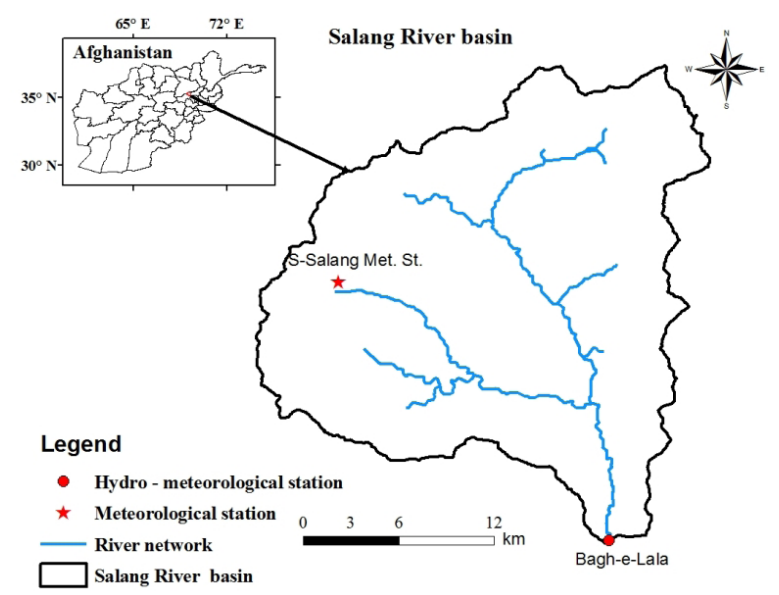

Figure 1 : Location map of Salang River basin, Afghanistan. 
covers a total area of $485.9 \mathrm{~km}^{2}$ and is situated between latitude $35.7^{\circ} \mathrm{N}$ and $35.25^{\circ} \mathrm{N}$ and longitude $69.0^{\circ} \mathrm{E}$ and $69.45^{\circ} \mathrm{E}$. The minimum and maximum elevation of the basin ranges from 1653 ma.s.1. to 4770 ma.s.1., respectively, with an average elevation of 2953ma.s.1. The basin has one hydro-meteorological station and one meteorological station, namely, Bagh-eala hydro-meteorological station (1653ma.s.1.) and South Salang meteorological station (3172ma.s.1.). Figure 1 shows the location of the major river systems in the basin and the hydrometeorological stations present in the basin.

The annual mean temperature recorded in Bagh-e-Lala hydro-meteorological station from January 2009 to May 2013 was $14.8^{\circ} \mathrm{C}$ with a maximum monthly mean temperature of $26.8^{\circ} \mathrm{C}$ in August 2009 and a minimum monthly mean temperature of $-1.9^{\circ} \mathrm{C}$ in February 2012 . Similarly, the annual total precipitation for the year 2009 was $587.4 \mathrm{~mm}$. The annual mean discharge recorded in this station from January 2009 to December 2012 ranged from $9 \mathrm{~m}^{3} \mathrm{~s}^{-1}$ to $12 \mathrm{~m}^{3} \mathrm{~s}^{-1}$, with a maximum monthly mean discharge of $41 \mathrm{~m}^{3} \mathrm{~s}^{-1}$ recorded in April 2012 and a minimum monthly mean discharge of $1 \mathrm{~m}^{3} \mathrm{~s}^{-1}$ in January 2012.

\section{DATA COLLECTION AND METHODS}

\subsection{Data Collection}

\subsubsection{Basin area and elevation distribution}

The Digital Elevation Model (DEM) downloaded from http://gdex.cr.usgs.gov/ gdex/, with horizontal resolution of $30 \times 30$ m obtained from the United States Geological Survey (USGS) is used in this study. ArcMap 9.3 is used to calculate the area and the areaelevation distribution of the basin. As the physical environment varies drastically with
Table 1 Elevation zone, elevation range, hypsometric mean elevation and zonal area for the 16 elevation zones of Salang River basin

\begin{tabular}{cccc}
\hline $\begin{array}{c}\text { Elevation } \\
\text { zone }\end{array}$ & $\begin{array}{c}\text { Elevation } \\
\text { range } \\
\text { (m a.s.l.) }\end{array}$ & $\begin{array}{c}\text { Hypsometric } \\
\text { mean } \\
\text { elevation } \\
\text { (m a.s.l.) }\end{array}$ & $\begin{array}{c}\text { Zonal } \\
\text { area } \\
\left(\mathbf{k m}^{2)}\right.\end{array}$ \\
\hline 1 & $1653-1853$ & 1748 & 3.5 \\
2 & $1853-2053$ & 1940 & 11.8 \\
3 & $2053-2253$ & 2150 & 26.8 \\
4 & $2253-2453$ & 2355 & 46.4 \\
5 & $2453-2653$ & 2540 & 57.2 \\
6 & $2653-2853$ & 2738 & 67.0 \\
7 & $2853-3053$ & 2955 & 63.1 \\
8 & $3053-3253$ & 3215 & 51.5 \\
9 & $3253-3453$ & 3370 & 45.2 \\
10 & $3453-3653$ & 3583 & 38.5 \\
11 & $3653-3853$ & 3783 & 29.7 \\
12 & $3853-4053$ & 3978 & 21.2 \\
13 & $4053-4253$ & 4178 & 15.8 \\
14 & $4253-4453$ & 4404 & 5.8 \\
15 & $4453-4653$ & 4620 & 1.9 \\
16 & $4653-4770$ & 4711 & 0.3 \\
\hline
\end{tabular}

increasing altitudes, the basin's great elevation range is divided into several zones to better describe the physical environment (Tahir et al., 2011). Hence, the study area is divided into 16 elevation zones, each with a vertical difference of $200 \mathrm{~m}$ (Table 1). The area-elevation curve (Figure 2) is used to determine the zonal

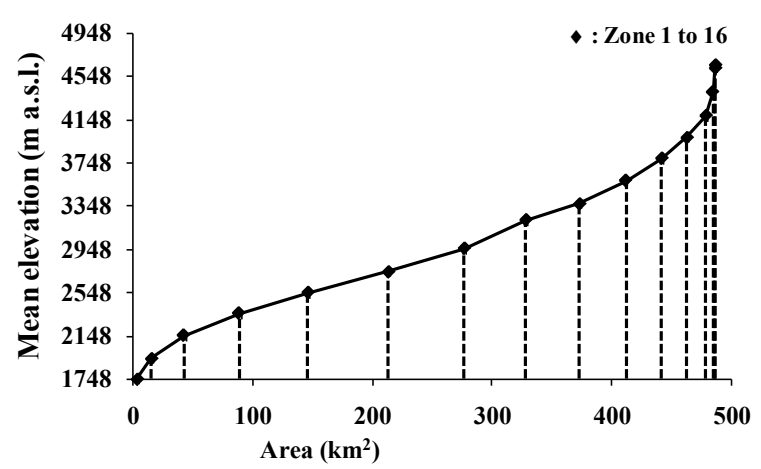

Figure 2 : Area - elevation curve of Salang River basin 
mean hypsometric elevations. Temperature and precipitation of each elevation zone are extrapolated for the calculation of zonal degreedays and zonal precipitation.

\subsubsection{Temperature}

In order to compute the daily snowmelt from the SRM, the number of degree-days must be determined from mean temperature data for each zone. In this study, the temperature obtained from Bagh-e-Lala hydro-meteorological station is used to estimate the mean temperature corresponding to the mean elevation of each zone using the temperature lapse rate. Due to the lack of historical data, the temperature lapse rate of Panjshir River basin situated nearby to the Salang River basin is used, which is calculated from the temperature data of two hydro-meteorological stations: Gul Bahar hydro-meteorological station (1605 m a.s.1.) and Du Ab hydro-meteorological station (2065 $\mathrm{m}$ a.s.l). The calculated average lapse rate of $0.91{ }^{\circ} \mathrm{C}$ per $100 \mathrm{~m}$ is used.

\subsubsection{Precipitation}

Extrapolating precipitation is particularly difficult in mountainous watersheds because of the lack of weather stations in the watershed and local factors, such as topography, which strongly influence the spatial distribution. In this study, precipitation recorded at Bagh-eLala hydro-meteorological station and South Salang meteorological station are used to calculate the precipitation gradient, which is found to be $1.7 \%$ increase per 100 m elevation rise. The calculated precipitation gradient is then used to estimate the precipitation at each elevation zone.
Precipitation usually occurs in two forms, i.e. rain or snow, which can be determined by a critical temperature in this model. When temperature is higher than the critical temperature, the precipitation is determined to be rain; otherwise, the precipitation is determined to be snow. The distinction between rain and snow is important in the SRM because the rain contribution to runoff occurs at about the same time as when rain occurs, whereas snow contribution to runoff is usually delayed until conditions for melt occur.

\subsubsection{Snow Cover}

Satellite-derived snow covered area is the best routinely available input for SRM, especially in remote and data-scarce mountain watersheds. Compared with other satellite platforms, the Moderate Resolution Imaging Spectroradiometer (MODIS) derived snow cover area is the most suitable for use in snowmelt models because of a higher spatial resolution $(500 \mathrm{~m})$ and location accuracy (Tekeli et al., 2005). In this study, MODIS/Terra Snow Cover 8 - Day L3 Global 500 m (MOD10A2) data set is downloaded from National Aeronautics and Space Administration's Earth Observing System Data and Information System. It is considered to be one of the best resources for remotely sensed information on the distribution of snow covered area over eight-day periods (Hall et al., 2002).

Although MODIS provides both daily and 8-day snow cover products, the 8 - day maximum snow-cover extent product is used to minimize cloud cover effect. The data sets thus obtained are processed through a MODIS Re-projection Tool (MRT) (Dwyer and Schmidt, 2006) with the WGS 1984 UTM Zone 42N projection system 


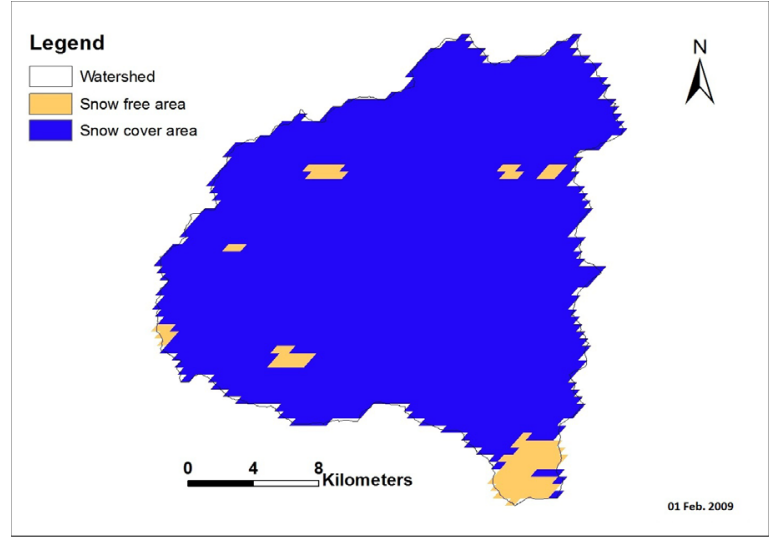

Figure 3 : Snow covered area in 2009

to get the 8 - day maximum snow covers for the Salang River basin, which are then interpolated to get daily snow cover data required to run the SRM. The snow covered area is calculated for the sixteen different altitudinal zones for snowmelt runoff modeling. We calculate the percentage of annual average snow covered area in 2009, 2010 and 2011 as 47\%, 30\% and $41 \%$, respectively. The snow covered area for 2009 is shown in Figure 3.

\subsection{Methods}

\subsubsection{Snowmelt Runoff Model (SRM)}

The SRM is one of the very few models in the world today that require remote sensing derived

Table 2

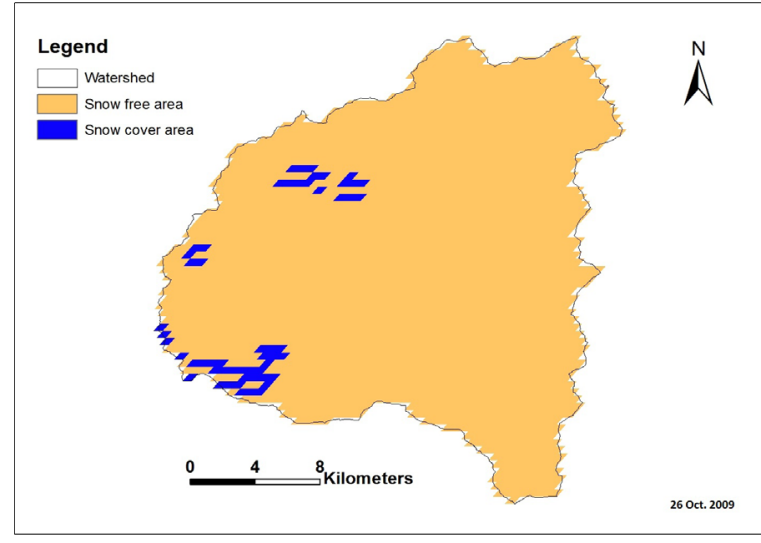

snow cover as model input. Owing to its simple data requirements and use of remote sensing to provide snow cover information, SRM is ideal for use in data sparse regions, particularly in remote and inaccessible high mountain watersheds (Hong and Guodong, 2003).

Daily temperature and precipitation data along with daily snow cover are the three basic input variables required for the operation of the model; and temperature lapse rate, runoff coefficient (for rain and snow), degree-day factor, recession coefficient, critical temperature, rainfallcontributing area, and lag time are the eight model parameters (Table 2).

In SRM, the runoff produced from snowmelt and rainfall is computed, superimposed on the calculated recession flow and transformed into

\begin{tabular}{lll}
\hline \multicolumn{1}{c}{ Parameters } & \multicolumn{1}{c}{ Description } & \multicolumn{1}{c}{ Value } \\
\hline $\mathbf{r}$ & Temperature lapse rate $\left({ }^{\circ} \mathrm{C}\right.$ per $\left.100 \mathrm{~m}\right)$ & $0.91{ }^{\circ} \mathrm{C}$ per $100 \mathrm{~m}$ \\
$\mathbf{T}_{\text {Crit }}$ & Critical temperature $\left({ }^{\circ} \mathrm{C}\right)$ & $0{ }^{\circ} \mathrm{C}$ \\
$\mathbf{a}_{\mathbf{n}}$ & Degree day factor $\left(\mathrm{cm}^{\circ} \mathrm{C}^{-1} \mathrm{day}^{-1}\right)$ & $0.9 \mathrm{~cm}^{\circ} \mathrm{C}^{-1} \mathrm{day}^{-1}$ \\
$\mathbf{L a g}$ time & Time lag (hour) & 6 hour \\
$\mathbf{C s}$ & Runoff coefficient for snow & 0.34 \\
$\mathbf{C r}$ & Runoff coefficient for rain & 0.15 \\
$\mathbf{X}$ & $\mathrm{X}-$ coefficient & 1.2 \\
$\mathbf{Y}$ & y - coefficient & 0.1 \\
$\mathbf{R C A}$ & Rainfall contributing area (option) & 1 \\
\hline
\end{tabular}


daily discharge from the basin according to the equation (1) given by Martinec et al. (2008):

$l_{n+1}=\left[C_{S_{n}} a_{n}\left(T_{n}+\Delta T_{n}\right) S_{n}+C_{R_{n}} P_{n}\right]+\frac{A_{1} 1000}{86400}\left(1-K_{n+1}\right)+C_{n} K_{n+1} \ldots \ldots \ldots \ldots . . . .(1)$

where $\mathrm{Q}$ is average daily discharge $\left(\mathrm{m}^{3} \mathrm{~s}^{-1}\right) ; \mathrm{C}_{\mathrm{S}}$ and $\mathrm{C}_{\mathrm{R}}$ are the runoff coefficients that expresses the losses to discharge (ratio of volume of snowmelt (rain) contributing to runoff to the total volume of snowmelt (rain)); $a$ is degreeday factor $\left(\mathrm{cm}^{\circ} \mathrm{C}^{-1} \mathrm{~d}^{-1}\right)$; $\mathrm{T}$ is number of degree days $\left({ }^{\circ} \mathrm{C} \mathrm{d}\right) ; \Delta \mathrm{T}$ is the adjustment by temperature lapse rate $\left({ }^{\circ} \mathrm{C} \mathrm{d}\right) ; \mathrm{S}$ is ratio of the snow cover to the total area; $\mathrm{P}$ is the precipitation contributing to runoff $(\mathrm{cm}) ; \mathrm{T}_{\text {CRIT }}$ is the critical temperature that determines whether this contribution is rainfall and immediate runoff. If precipitation is determined by $\mathrm{T}_{\text {CRIT }}$ to be new snow, it is kept on storage over the hitherto snow free area until melting conditions occur; $\mathrm{A}$ is area of the basin or zone $\left(\mathrm{km}^{2}\right)$; $\mathrm{n}$ is sequence of days during the discharge computation period; $\frac{10000}{86400}=$ conversion from runoff depth $\left(\mathrm{cmkm} 2 \mathrm{~d}^{-1}\right)$ to discharge $\left(\mathrm{m}^{3} \mathrm{~s}^{-1}\right) . \mathrm{K}$ is a recession coefficient indicating the decline of discharge in the period without snowmelt or rainfall, $K=\frac{Q_{m+1}}{Q_{m}}$ (m, $\mathrm{m}+1$ are the sequence of days during a true recession flow period). The recession coefficient is an important model parameter since $(1-k)$ is the proportion of the daily melt-water of snow contributing to the daily runoff. Recession coefficient can be obtained by the analysis of historical discharge data based on the following equation:

$K_{n+1}=x \cdot Q_{n}^{-y}$

where $Q_{n}$ is discharge on day $n ; x$ and $y$ are two constants. For the determination of $x$ and $y$,

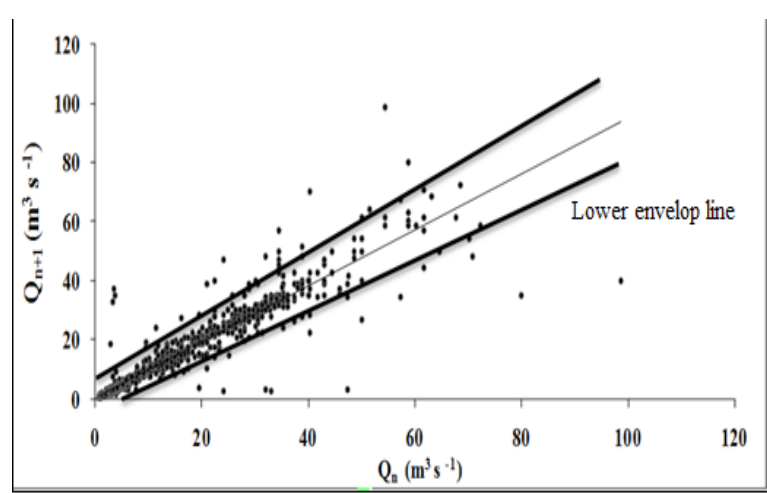

Figure 4 : Recession flow plot Qnvs Q n+1 forSalang River basin

daily discharge on a given day, $Q_{n}$, is plotted against the value on the following day, $Q_{n+1}$. Figure 4 illustrates the plotting of $Q_{n}$ and $Q_{n+1}$ for the $K$ value of the Salang River. For this basin, the lower envelop line, which passes through the lower discharge values, is used to calculate $\mathrm{x}$ and $\mathrm{y}$. The lowest and highest values of Qn that lie along the lower envelop line are used for the determination of $Q_{1}$ and $Q_{2}$. Based on the relation $\mathrm{K}=\frac{\mathrm{Q}_{\mathrm{n}+1}}{\mathrm{Q}_{\mathrm{n}}}$, it is derived that $k_{1}=1.23$ for $Q_{1}=72.3 \mathrm{~m}^{3} \mathrm{~s}^{-1}$ and $K_{2}=1.73$ for $Q_{2}=12.2 \mathrm{~m}^{3} \mathrm{~s}^{-1}$. Using these values in equation (2), the $\mathrm{x}$ and $\mathrm{y}$ are calculated which is given in Table 2. Equation (1) is for a time lag between the daily temperatures cycle and the resulting discharge cycle of 18 hours. Various lag times can be introduced by a sub-routine and for this basin; a lag time of 6 hrs is used for simulation which can be fed into the model

Another parameter called Rainfall Contribution Area (RCA) is used in this model to know whether runoff from rainfall is added to runoff due to snowmelt only from the snow free area (option 0 ) or from the entire basin or zonal area (option 1). In the present study option 1 is used for RCA, which means the runoff from rainfall is added to runoff due to snowmelt from the entire basin as shown in Table 2 . 


\subsection{Evaluation of model performance}

The computed and measured hydrographs show at the first glance whether the simulation is successful or not. In addition, SRM uses two accuracy criteria to evaluate model performance, namely, the coefficient of determination $\left(\mathrm{R}^{2}\right)$, and the volume difference $\mathrm{D}_{\mathrm{v}}$ (Martinec and Rango, 1989). The $\mathrm{R}^{2}$ is computed as:

$\mathrm{R}^{2}=1-\frac{\sum_{i=1}^{n}\left(Q_{i}-Q_{i}^{\prime}\right)^{2}}{\sum_{i=1}^{n}\left(Q_{i}-\bar{Q}\right)^{2}}$

where, $\mathrm{Q}_{\mathrm{i}}$ is measured daily discharge $\left(\mathrm{m}^{3} \mathrm{~s}^{-1}\right)$, $Q_{i}^{\prime}$ is simulated daily discharge $\left(\mathrm{m}^{3} \mathrm{~s}^{-1}\right), \bar{Q}$ is average measured discharge of the given year or snowmelt season $\left(\mathrm{m}^{3} \mathrm{~s}^{-1}\right)$ and $\mathrm{n}$ is the number of daily discharge values. Similarly, the volume difference $\left(\mathrm{D}_{\mathrm{v}}\right)$ in percentage is computed as:

$$
\mathrm{D}_{\mathrm{v}}=\frac{\mathrm{V}_{\mathrm{R}}-\mathrm{V}_{\mathrm{R}}^{\prime}}{\mathrm{V}_{\mathrm{R}}} \quad x 100
$$

where $V_{\mathrm{R}}$ is the measured runoff volume $\left(\mathrm{m}^{3}\right)$ and $V_{R}$ is the simulated runoff volume.

\section{RESULTS AND DISCUSSION}

\subsection{Model calibration and validation}

In this study, the model has been calibrated for 2009 due to its good hydro-meteorological records and validated for 2010 and 2011. Parameter adjustment is carried out manually by using a trial-and-error method. The values of the main parameters for SRM in the Salang River basin are listed in Table 1. The measured and computed discharge hydrographs for the calibration year 2009 are shown in Figure 5. The observed and calculated annual average discharges for 2009 are $11.57 \mathrm{~m}^{3} \mathrm{~s}^{-1}$ and $10.73 \mathrm{~m}^{3} \mathrm{~s}^{-1}$, respectively and the results are good with an $\mathrm{R}^{2}$ value and $\mathrm{D}_{\mathrm{v}}$ of 0.87 and $7.18 \%$, respectively.

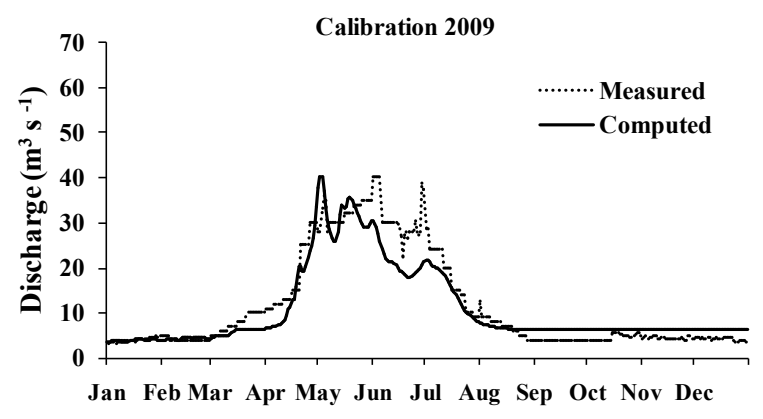

Figure 5 : Observed and computed discharges of Salang River basin (2009)

After getting good results from the calibration period, the model is validated for 2010 and 2011 as shown in Figure 6. The observed and calculated annual average discharges for 2010 are $11.55 \mathrm{~m}^{3} \mathrm{~s}^{-1}$ and $10.07 \mathrm{~m}^{3} \mathrm{~s}^{-1}$, respectively and the resulting $\mathrm{R}^{2}$ and $\mathrm{D}_{\mathrm{v}}$ values are 0.43 and $12.8 \%$, respectively. Similarly, for 2011 the observed and calculated annual average discharges are $9.05 \mathrm{~m}^{3} \mathrm{~s}^{-1}$ and $9.6 \mathrm{~m}^{3} \mathrm{~s}^{-1}$, respectively and the resulting $\mathrm{R}^{2}$ and $\mathrm{D}_{\mathrm{v}}$ values are 0.69 and $-6.9 \%$, respectively.

In our study, the model did not simulate the peak stream flows well in summer months. The relatively low $\mathrm{R}^{2}$ values and the high volume differences in the validation years obtained in our study are attributed to the underestimates of those peak flows and contribution of ground water in the hydrographs. As there is very little or no precipitation during the summer season in this basin, the peaks obtained in the observed discharge hydrographs may be due to the sudden hydrologic events such as flash

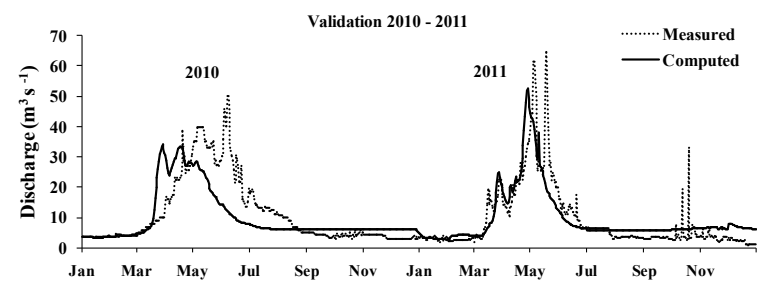

Figure 6 : Observed and computed discharges of Salang River basin (2010 - 2011) 
floods that could not be simulated by the model. Hence, considering the limited measurements available, the performance of the SRM is found to be satisfactory.

\subsection{Impact of change in temperature and precipitation on river discharge}

It is very important to study the changing pattern of river flow in the changed temperature and precipitation scenario, not only for future planning of new water resources projects but to maintain and operate the existing water schemes. The snow-fed sources of water are extremely sensitive to the changing precipitation and temperature parameters over the time. Hence, after good calibration of the model, it is also used to study the change in stream flow due to change in temperature and precipitation (Figure 7). Four climate scenarios are considered for discharge simulation, namely i) increase in $1^{\circ} \mathrm{C}$ temperature and $10 \%$ precipitation, ii) increase in $2^{\circ} \mathrm{C}$ temperature and $20 \%$ precipitation, iii) decrease in $1{ }^{\circ} \mathrm{C}$ temperature and $10 \%$ precipitation, and iv) decrease in $2^{\circ} \mathrm{C}$ temperature and $20 \%$ precipitation. However, the snow cover area for this analysis is kept constant in all these scenarios due to difficulty in predicting future snow cover data.

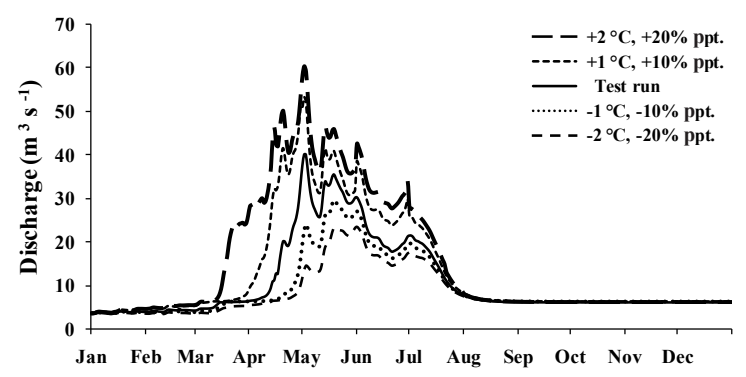

Figure 7 : Change in calculated discharge by changing temperature and precipitation (2009)

From the result shown in Figure 6, among these four scenarios, the increase in discharge is highest when the temperature and precipitation is increased by $2{ }^{\circ} \mathrm{C}$ and $20 \%$, respectively, whereas the decrease in discharge is more when the temperature and precipitation is decreased by $2^{\circ} \mathrm{C}$ and $20 \%$, respectively. With the increase of $1{ }^{\circ} \mathrm{C}$ temperature and $10 \%$ precipitation, the annual discharge is increased by $14.8 \%$, whereas with increase of $2{ }^{\circ} \mathrm{C}$ temperature and $20 \%$ precipitation, annual discharge is increased by $44.1 \%$. Similarly, the results for other climate scenarios are shown in Table 3 and Figure 8.

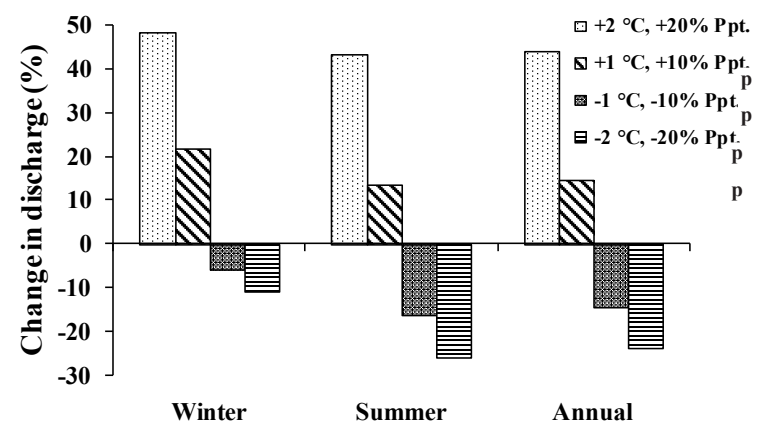

Figure 8 : Percentage change in discharge for different climate scenarios with the test run (2009)

From the analysis, we found that the stream flow in winter season is likely to increase more with the increased temperature and precipitation, whereas the stream flow in summer season is likely to decrease more with the decreased temperature and precipitation. However, the increase of temperature will melt snow earlier only if precipitation remains the same.

Table 3

\begin{tabular}{lcccc}
\hline & $\mathbf{- 1}{ }^{\circ} \mathbf{C}$, & $\mathbf{- 2}{ }^{\circ} \mathbf{C}$, & $+\mathbf{1}^{\circ} \mathbf{C}$, & $+2{ }^{\circ} \mathbf{C}$, \\
& $\mathbf{- 1 0 \%}$ & $\mathbf{- 2 0 \%}$ & $+\mathbf{1 0} \%$ & $+\mathbf{2 0 \%}$ \\
& $\mathbf{P p t}$. & Ppt. & Ppt. & Ppt. \\
\hline Winter & -5.8 & -10.9 & 21.8 & 48.5 \\
Summer & -16.2 & -26.0 & 13.5 & 43.3 \\
Annual & -14.6 & -23.6 & 14.8 & 44.1 \\
\hline
\end{tabular}




\section{CONCLUSION}

In this study, the SRM is used to estimate discharge from the Salang River basin, Afghanistan. The model is calibrated for 2009 and validated in 2010 and 2011. The observed and calculated annual average discharges for the calibration year are $11.57 \mathrm{~m}^{3} \mathrm{~s}^{-1}$ and $10.73 \mathrm{~m}^{3} \mathrm{~s}^{-1}$, respectively with $\mathrm{R}^{2}$ and $\mathrm{D}_{\mathrm{v}}$ values of 0.87 and $7.18 \%$, respectively. The observed and calculated annual average discharges for the validation year 2010 are $11.55 \mathrm{~m}^{3} \mathrm{~s}^{-1}$ and $10.07 \mathrm{~m}^{3} \mathrm{~s}^{-1}$, respectively and the resulting $\mathrm{R}^{2}$ and $\mathrm{D}_{\mathrm{v}}$ values are 0.43 and $12.8 \%$, respectively. Similarly, for 2011, the observed and calculated annual average discharges are $9.05 \mathrm{~m}^{3} \mathrm{~s}^{-1}$ and $9.6 \mathrm{~m}^{3} \mathrm{~s}^{-1}$, respectively and the resulting $\mathrm{R}^{2}$ value and $\mathrm{D}_{\mathrm{v}}$ are 0.69 and $-6.9 \%$. The model shows good results in the calibration year, however, it could not simulate the peak stream flows well in the validation years, thus the $\mathrm{R}^{2}$ values in these years are relatively lower. The model also estimates discharge of the basin by changing temperature and precipitation. When the temperature is increased by $1{ }^{\circ} \mathrm{C}$ and precipitation by $10 \%$, the annual discharge will increase by $14.8 \%$. Similarly, when the temperature is increased by $2{ }^{\circ} \mathrm{C}$ and precipitation by $20 \%$, the increase in annual discharge is by $44.1 \%$. The results obtained suggest that the SRM can be used to estimate the river discharge of snow fed mountainous river basins of Afghanistan.

\section{ACKNOWLEDGEMENTS}

We would like to acknowledge the Contribution to High Asia Runoff from Ice and Snow (CHARIS) project of the University of Colorado at Boulder, USA funded by the USAID for financial support to carry out this research. We thank the reviewer Mary Jo Brodzik, The
University of Colorado (CU), Boulder, USA for her constructive comments and suggestions. We also thank to Alana Wilson, CU, Boulder, USA for her kind help to improve the manuscript in the initial phase. We would like to thank the Geosciences Faculty, Department of HydroMeteorology, Kabul University, the Ministry of Water and Power, Government of Afghanistan, the Ministry of Mines, Government of Afghanistan, the Geodesy and Cartography Office, Government of Afghanistan for providing necessary data. We would also like to thank all members of the Himalayan Cryosphere, Climate and Disaster Research Center (HiCCDRC), Kathmandu University for their valuable supports.

\section{REFERENCES}

Abudu, S., Cui, C., King, J. P., Abudukadeer, K., 2010. Comparison of performance of statistical models in forecasting monthly streamflow of Kizil River, China. Water Science and Engineering, 3 (3), 269-281.

Dwyer, M. J., \& Schmidt, G. (2006). The MODIS reprojection tool. In Earth science satellite remote sensing (pp. 162-177). Springer Berlin Heidelberg.

Favre, R., Kamal, G. M., 2004. Watershed ATLAS of Afghanistan, $1^{\text {st }}$ edition - working document for planners, Afghanistan Information Management Services, Kabul, Afghanistan.

Hall, D. K., Riggs, G. A., Salomonson, V. V., Giromamo, N. D., Bayr, K. J., 2002. MODIS Snow-Cover Products. Remote Sensing of Environment, 83, 181-94 
Hong, M. A., Guodong, C., 2003. A test of Snowmelt Runoff Model (SRM) for the Gongnaisi River basin in the Western Tianshan Mountains, China. Chinese Science Bulletin.48 (20), 2253 - 2259.

Leavesley, G. H., 1994. Modeling the effects of climate change on water resources - a review. Climatic Change 28, 159-177

Li, X., Williams, M. W., 2008.Snowmelt runoff modeling in an arid mountain watershed, Tarim Basin, China. Hydrological Processes, 7098.

Martinec, J., Rango, A., 1989. Accuracy of snowmelt runoff simulation, Nordic Hydrology 12(4/5), 265 - 274.

Martinec. J., Rango, A., Major, E., 1983. The Snowmelt-Runoff Model (SRM) User's Manual NASA Ref. Publ. 1100 Washington, DC

Martinec, J., Rango, A., Roberts, R., 2008. Snowmelt Runoff Model (SRM) User's guide Manual. New Mexico, State University, Las Cruces, USA.

Raghunath, H. M., 2006. Hydrology: Principle, Analysis and Design. New Age International (P) Ltd, New Delhi, India, 407-412.
Seidel, K., Martinec, J., 2004.Remote sensing in snow hydrology.Springer.

Tahir, A. A., Chevallier, P., Arnaud, Y., Ahmad, B., 2011. Snow cover dynamics and hydrological regime of the Hunza River basin, Karakoram Range, Northern Pakistan. Hydrology and Earth System Sciences 15 (7), 2275-2290.

Tekeli, A. E., Akyurek, Z., Sorman, A. A., Sensoy, A., Sorman, A. U., 2005. Using MODIS snow cover maps in modeling snowmelt runoff process in the eastern part of Turkey. Remote Sensing of Environment, 97, 216-230.

World Meteorological Organization (WMO), 1986.Intercomparison of Models of Snowmelt Runoff.Operational Hydrology Report. (Geneva: Secretariat of the World Meteorological Organization).

World Meteorological Organization (WMO), 1992.Simulated real-time intercomparison of hydrological models Operational Hydrology Report. (Geneva: World Meteorological Organization) 